\title{
A HIDROSZFÉRA FELSZÍNI LEFOLYÁSNYOMAI - FOLYÓVÖLGYEK A MARSON
}

\author{
Steinmann Vilmos ${ }^{(1),(2)}$ \\ (1) Eötvös Loránd Tudományegyetem, Természetföldrajzi Tanszék, \\ Budapest, Pázmány Péter sétány 1/C, 1117 \\ ${ }^{(2)}$ ELKH Csillagászati és Földtudományi Kutatóközpont, Konkoly Thege Csillagászati \\ Intézet, 1121 Budapest, Konkoly-Thege Miklós út 15-17, \\ e-mail: steinmann.vilmos@csfk.mta.hu
}

Surface runoff features of a hydrosphere - fluvial valleys on Mars

\begin{abstract}
The global water circulation on the Mars might have been resembled to those of today, in the Earth. The valley at the studied area might have been initiated by a big flood and later smaller discharge flow; all of the geomorphological features are agreement with the presence of flowing water. The cross-section profile showed ' $\mathrm{V}$ ' shape at the upper section of the valley and this shape turn to a ' $U$ ' shape toward the lower section. The estimated age of the valley was $2,9(+0,3 ;-0,5) \mathrm{Ga}$, what was estimated using crater statistics, what is somewhat later then the age of the ancient wet period of the Mars, what is called Noachian. The studied valley shows some correlation in morphology with the dry/semi-dry terrestrial valley, the wadis.
\end{abstract}

Keywords: Mars, fluvial valleys, hydrosphere

\section{Összefoglalás}

A marsi víz körforgása részben hasonló lehetett a földi víz körforgásához (vagy más néven hidrológiai ciklus, amely a víz természetes folytonos körforgása melyet a Nap sugárzáságából származó energia tart fenn), amelyben a felszíni lefolyás nyomai látványos folyóvölgyek formájában ma is megfigyelhetőek a Marson. A dolgozatban vizsgált marsi völgyet egy áradás hozhatta létre, de a benne található geomorfológiai formák a folyóvíz tartós jelenlétére utalnak. Megtalálható a földi folyóvölgyek számos jellemzője, kezdve a különböző völgytípusoktól, a keresztmetszeti hasonlóságokon át egészen a feltételezett hordalékkúp alakjáig. A völgy sok hasonlóságot mutat a földi, föleg a sivatagos félsivatagos területeken kialakult vádi típusú vízfolyásokkal. A vizsgált völgy hossza megközelítőleg $81 \mathrm{~km}$, átlagos szélessége $1,85 \mathrm{~km}$. A keresztszelvények alakja a völgy irányával együtt változik, a felső szakaszon 'V', de egyre északabbra haladva folyamatosan kiszélesedik és 'U' alakot vesz fel. A völgy kora a kráterstatisztikai vizsgálatok alapján egybeesik a vörös bolygó nedvesnek feltételezett (a felszínen nagyobb mennyiségü folyékony vízzel rendelkező) időszakával a Noachi korral.

Kulcsszavak: Mars, folyóvölgyek, hidroszféra

\section{Bevezetés}

A Mars ősi, feltételezett hidroszférája érdekes célpont, amelyet a Föld jelenlegi hidroszférájával összehasonlítva általános megállapításokat nyerhetünk. A marsi víz egykori nyomai igen 
változatos morfológiai formákban azonosíthatóak a bolygón (Kereszturi, 2012b), amelyek között a folyóvölgyek (Hargitai \& Kereszturi, 2015) a leglátványosabbak. Az egykori vizes környezetek a leszállóhelyek kijelölésében is fontosak (Ettahri et al., 2018; Kereszturi \& Orgel, 2018), ahol a felszínen a külső erők szállította szemcsék (Kapui et al., 2018) és vizes mállásnyomok (Marschall et al., 2015) elemzése is segít az ősi hidroszféra előfordulásának és következményeinek a becslésében. A víz napjainkban nagyon ritkán és feltehetöleg csak mikroszkopikus skálán jelenhet meg a bolygón (Pál \& Kereszturi, 2017 és 2020), de fagyott állapotban ma is gyakori (Hauber et al., 2015). Korábban (a már említett noachi korban) a cseppfolyós fázis is gyakoribb lehetett (Kereszturi, 2012a, b). Mindez a marsi élet kialakulási lehetőségével kapcsolatban is fontos kutatási témát jelent (Domagal-Goldman et al., 2016), amelynek ma már sokkal rosszabb esélyei vannak, de elöfordulását kizárni még nem lehet (Horváth et al., 2009; Marschall et al., 2012; de Vera et al., 2014).

A marsi folyóvölgyek közül sok, idős kora ellenére, a gyenge erózió miatt jó állapotban maradt fent. Ezek közül a legtöbb a bolygó korai ún. Noachi időszakában jött létre, mintegy 3,7 milliárd évvel ezelőtti időpontig. Ebben a korai fázisban sok folyóvölgy tónyomokkal és üledékes torkolati képződményekkel kapcsolódik össze (Kereszturi, 2013a, b; Hargitai et al., 2017, 2018), amelyek együttesen viszonylag gazdag felszíni lefolyást, tárózódást és kölcsönhatásrendszert jelölnek. Az alábbiakban egy, a fenti időszakot jellemző, de a nemzetközi irodalomban részletesen még nem vizsgált folyóvölgy és hozzá kapcsolódó jellemzők bemutatása olvasható, amely ideális esetben tipikus példát mutat arra, hogy miként tudjuk vizsgálni az ősi marsi hidroszféra felszíni lefolyásával kapcsolatos jellemzőket.

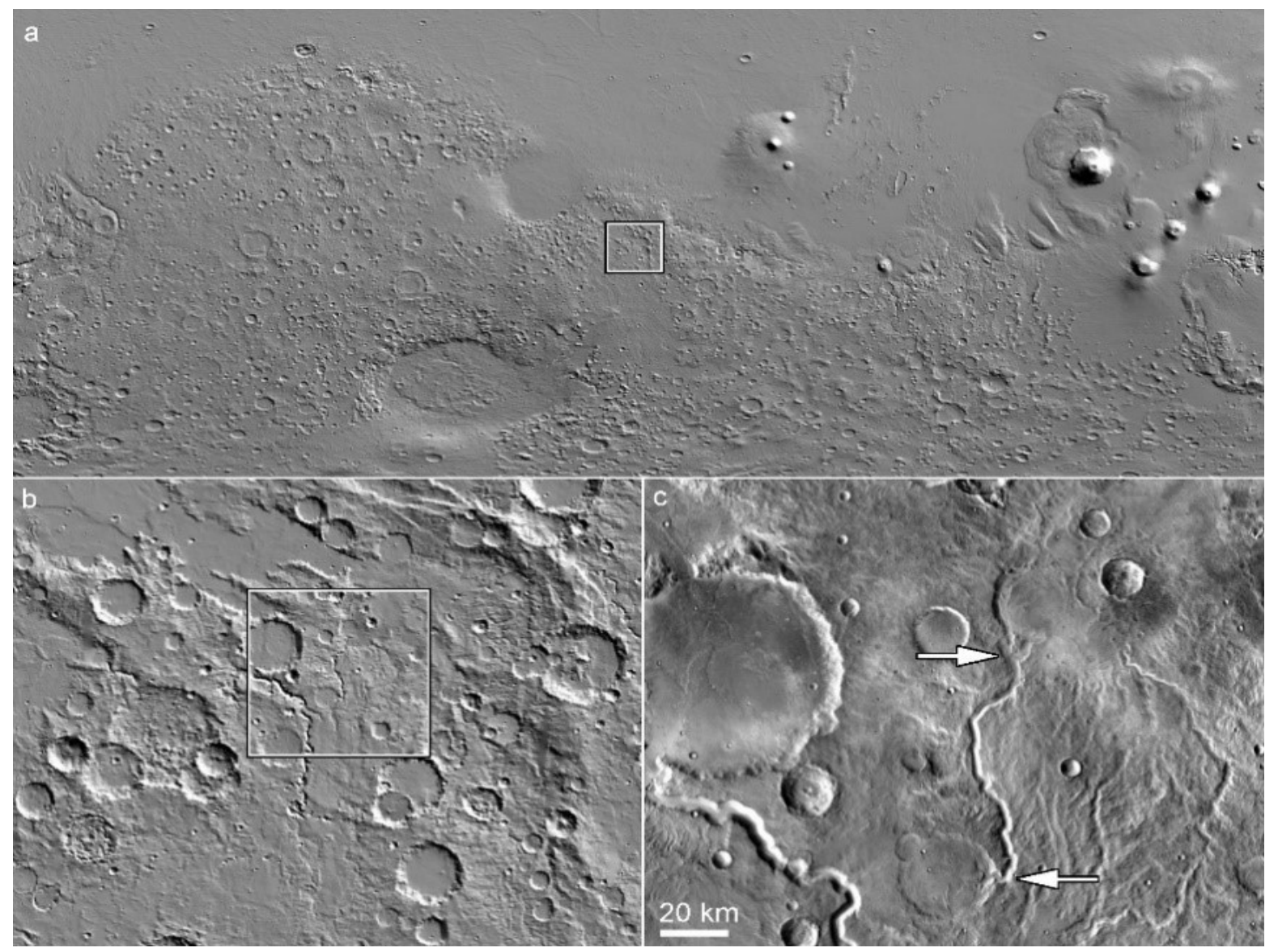

1. ábra: Áttekintő térkép a vizsgált terület tágabb környezetéről.

Figure 1: Overview of the analysed terrain. 
A vizsgált terület a Mars déli féltekéjén található a marsi Egyenlítőhöz közel (d. sz. $2^{\circ} 55^{\text {' }}$ k. h. 111 $53^{\prime}$ '). A Tinto 'B' nevet a töle keletre található Tinto völgyröl (Tinto Valley) kapta a könnyebb beazonosítás miatt (Rauhala \& Kostama, 2012). Hossza megközelítőleg $81 \mathrm{~km}$, szélessége átlagosan $1,85 \mathrm{~km}$. A völgyfö a déli kráter peremén +400 méter magasságban, míg a torkolat -756 méteren az északi, nagyobb kráternél található (1. ábra). A vizsgált völgytől nyugatra egy idősebb, fonatos mintázatot mutató sekély völgyhálózat található. A völgy és a környezö terület kora jól elkülönül egymástól. A völgynek a kráterstatisztikai adatokból becsült kora megközelítőleg $2,9(+0,3 ;-0,5) \mathrm{Ga}$ (milliárd év), míg a környező terület kora megközelítöleg $3,5(+0,05 ;-0,08)$ Ga (milliárd év).

\section{Munkamódszerek}

A kutatómunka ArcGIS nevü térinformatikai szoftverrel készült a legnagyobb arányban. A vizsgálat alapját egy domborzatmodell (DTM) alkotja, melynek felbontása 50 méter/pixel (m/px). A DTM a HRSC (High Resolution Stereo Camera) müszer mérésének eredménye, amely a Mars Express szondán teljesít szolgálatot. A morfológia meghatározására egy pankromatikus kép (CTX, Context Camera) kamera, Mars Roconnaissance Orbiter-ürszonda) is fel lett használva, melynek felbontása $6 \mathrm{~m} / \mathrm{px}$. A kép és a domborzati adatállomány azonos koordináta-rendszerben, a Sinusoidal_Mars 2000-ben van, aminek a lineáris mértékegysége méterben definiált.

A keresztmetszetek GlobalMapper programmal készültek, haladási irányuk megegyezik a völgyfal lejtési irányával. A numerikus adatok *.dbf formátumba való kiexportálása után azok MS Excel-ben lettek megjelenítve és formázva.

A völgyröl készült hossz-szelvény a QGIS szoftverben készült 100 méterenként elhelyezett pontok alapján, a magasság-értékek kijelölésével. Előzetesen, a már említett szoftver segítségével, csak azok a pixelek lettek ponttá alakítva, amelyekbe a környező pixelekböl a legtöbb hipotetikus folyadék áramlik (flow direction and flow accumulation).

A szintvonalak az egész völgy területére 25 m-es közzel lettek legenerálva az ArcMap programban.

\section{Eredmények}

A völgyről összesen 12 keresztmetszet készült, közel egyenletes eloszlásban, amelyek lefedik az egész völgyet. A keresztmetszetek hossza változó, de nem rövidebbek, mint $1000 \mathrm{~m}$ és nem haladják meg az 1500 m-t. A 2. ábrán látható hossz-szelvény a völgyfőtől, egészen a völgy torkolatáig tart, hossza $81 \mathrm{~km}$. Az eredeti pontsor nem adja ki teljesen a völgy alakját (kék görbe), ezért az eredeti pontsor el lett simítva egy 5-öd fokú polinominális függvénnyel, így jobban látható a völgy lejtése és hosszanti alakja.

A keresztmetszetekből származó megfigyelések alapján a völgy három szakaszra tagolható. A déli (felső) szakasz V-alakú keresztmetszettel rendelkezik. A völgy közepe átmeneti jelleget mutat, észak felé haladva egyre szélesedő völgytalppal. A völgy északi részéröl készült keresztszelvények U-alakúak, a völgytalp jelentősen szélesedik a folyásiránynak megfelelően. A legutolsó északi szakaszról készült szelvényen terasz-szerü képződmények is láthatóak egy, a fő völgybe (Tinto B) nyugati irányból befolyó kisebb mellékvölgy torkolatánál található. 
Tinto 'B' hossz-szelvény



2. ábra: A vizsgált terület hossz-szelvénye (kék görbe) 5-öd fokú polinominális simítással (fekete görbe).

Figure 2: Longitudinal profile of the analyzed valley, blue marks the original data, black the smoothed curve by 5 th order polynomial smoothing.

A völgy három szakaszra bontható. A délen található magasabban fekvő szakasz $\mathrm{V}$-alakú völgyei egyértelmüen felső szakaszjelleget (föleg bevágódó, erózió dominálta) mutatnak. A völgy ezen részén a keresztmetszeteken kimutatható a völgyfalak omlásából származó törmelék, ami kiemelkedő formaként jelenik meg a keresztmetszeten. A völgyfalak ezen a szakaszon a legmeredekebbek. Az átlagos meredekség $25^{\circ}$ és $30^{\circ}$ között változik. Ez a völgykeresztmetszet megfelel a Földön is megtalálható gyors folyású folyók keresztmetszetének, ahol a lerakódás alárendelt, és főleg a pusztulás mutatkozik, így mélyítve az áramló víz a völgyét.

A középső szakaszon a völgy esése megközelítőleg $0,69^{\circ}$, ami közel fele a felső szakaszjelleget mutató résznek. A völgyfalak meredeksége átlagosan $20^{\circ}$. A völgy észak felé haladva folyamatosan szélesedik és közel U alakot vesz fel. A szélesedő völgytalppal párhuzamosan csökken a völgyfal lejtő meredeksége. A középső szakaszon a völgyfalon sürün találhatóak törmeléklejtők és törmelékszoknyák.

$\mathrm{Az}$ alsó, északi szakaszon a völgy esése csekély, mindössze $\sim 0,44^{\circ}$. A völgyfalak meredeksége ezen a szakaszon, csak 10-15 közötti, ami közelítőleg fele a felső szakaszjelleget mutató déli résznek. A széles völgy és a völgyfalak alacsony lejtése megfeleltethető a földi folyók jellegzetes alsó szakaszának. Ilyenkor a víztest nem erodálja a kőzetet, hanem a felsőbb szakaszon már lepusztított és szállítódott hordalékot lerakja, zátonyokat, szigeteket képez a torkolat környékén. Ezek a hordalékkúpok és zátonyok sejthetők mind a pankromatikus, felvételen, mind pedig a domborzatmodellből képzett szintvonalas térképen. 


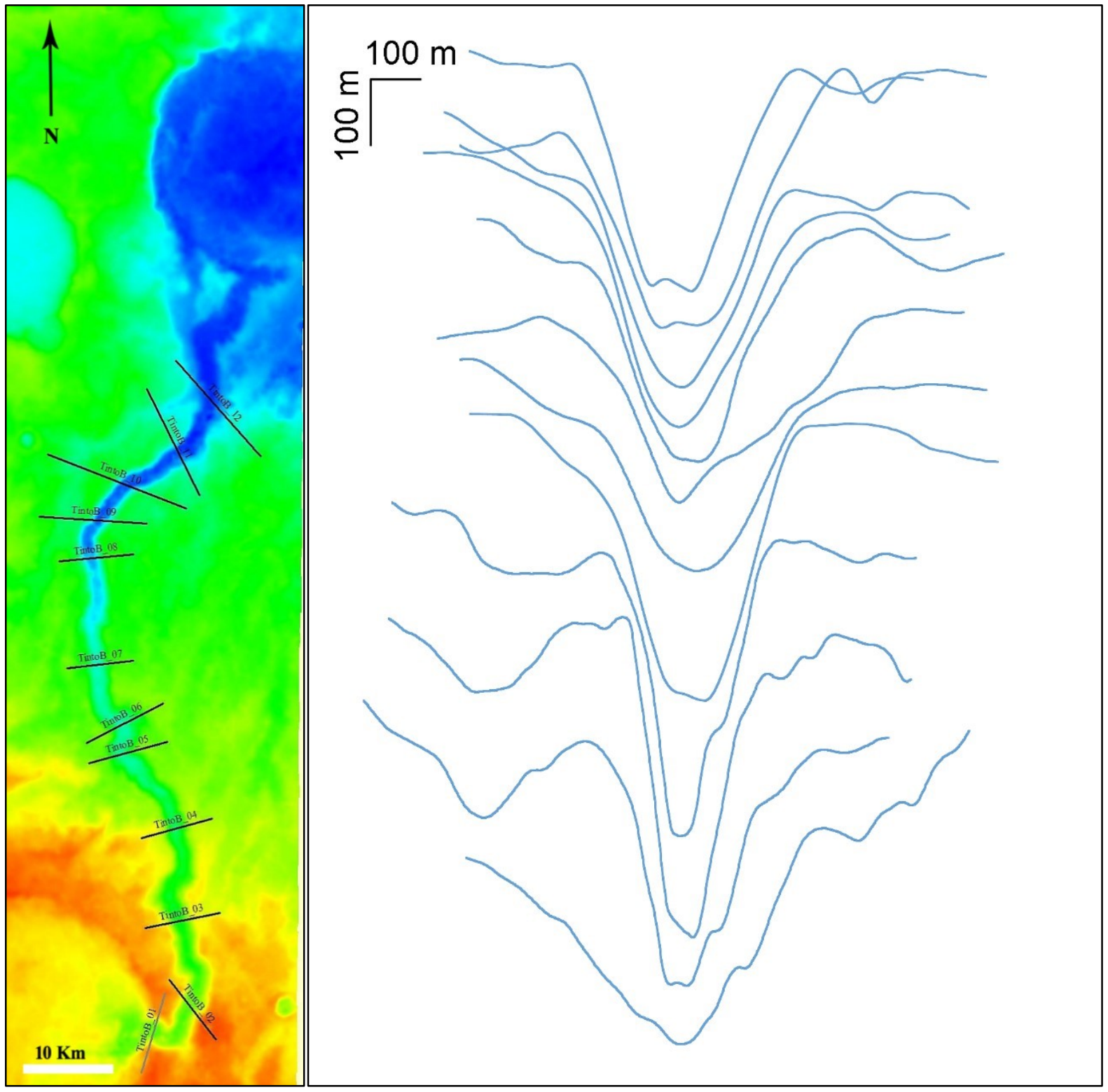

3. ábra: Áttekintő térkép a keresztszelvények helyzetéről a Tinto 'B' völgyén (bal oldali ábra).

Keresztszelvények a Tinto 'B' területén (jobb oldali ábra). Míg bal oldalon alulról felfelé haladunk folyásirányba, a jobb oldali képen fentről lefelé sorakozó szelvények követik egymást folyásirányba.

Figure 3: Map of the locations of the cross-sectional profiles (left) along Tinto-B valley, the crosssectional profiles can be seen at right. While at left the profiles are arranged upward into flow-ward

direction, at right they are ordered from the top toward the bottom in flow-ward direction.

A vizsgált terület alsó szakaszán 3 terasz-szerủ morfológiai elem is található (T1-T3), míg a völgy más részein nem mutatkozik hasonló jellegü képződmény. A völgy bal oldalfalán ott alakultak ki teraszok, ahol a már fonatos mellékvölgy-hálózat beletorkollik a vizsgált „,fóvölgybe”. A teraszok kialakulása földi körülmények között, sok esetben, a glaciálisinterglaciális változásoknak köszönhetők. Teraszok keletkezhetnek a víz erodáló munkája miatt is, ami „egyenetlen” (erősen változó) áramlási sebességre utal. Azonban a Marson erre utaló nyomokat még nem fedeztek fel, ezért nem jelenthetjük ki, hogy ezek a képződmények valóban teraszok lennének.

Elképzelhető, hogy a völgyfal északi szakasza (ahol a már említett nyugati kisebb mellékvölgy betorkollik a fö völgybe) különböző keménységü kőzetek rétegeiből épül fel. 
A víz a gyengébb ellenálló képességgel rendelkező kőzetet jobban erodálta, míg a keményebb kőzet a közvetlenül alatta elhelyezkedő kőzetanyagot megvédte, ezt a folyamatot a szelektív denudáció ( $\approx$ kőzetminőséghez igazoldó lepusztulás) fogalmával definiáljuk. Így a szelektív denudáció hatása miatt alakulhatott ki ez a lépcsőszerü, terasz-szerü forma a völgy ezen szakaszán.

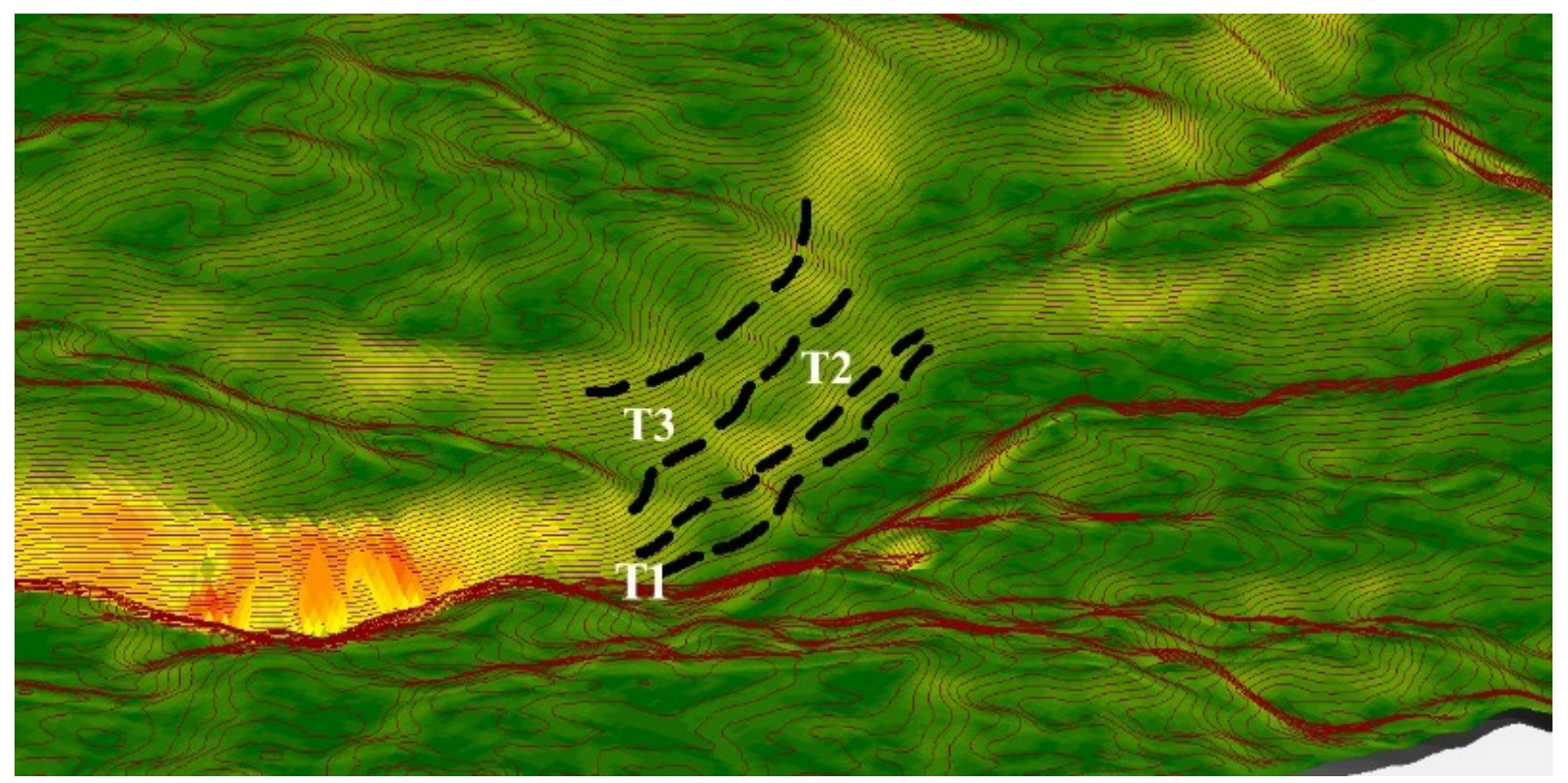

4. ábra: Lehetséges álteraszok (T1-T3) a vizsgált terület kifolyásánál (3D-s ábra).

Figure 4: Candidate pseudo-terraces (T1-T3) at the lower section of the valley.

\section{Összefoglaló következtetések}

Egy 2,9 milliárd évesnek talált marsi folyóvölgy elemzése bepillantást enged az egykori hidroszféra jellemzőibe. A megfigyelések domborzatmodelleken és pankromatikus képeken történtek a lehetö legjobb felbontásban, ami a domborzati modell esetében $50 \mathrm{~m} / \mathrm{px}$, míg a pankromatikus felvétel esetében $6 \mathrm{~m} / \mathrm{px}$ volt. A vizsgált folyóvölgy jól elkülöníthető szakaszokból áll, amelyek a keresztszelvények alakja alapján határolhatóak le. Ezek a jellegzetességek, mint például a felső szakasz 'V' alakú keresztmetszete, vagy a hordalékkúpok megjelenése az alsó szakaszon nagyon hasonlítanak a Földön is megtalálható, folyóvíz által kialakított formákhoz. A völgy legérdekesebb eleme az alsó szakaszon található három teraszszerü forma, ami a víz miatti szelektív denudáció során alakulhatott ki. A vizsgált völgy legjobb földi analógiái a sivatagos, félsivatagos területeken található vádik.

\section{Köszönetnyilvánítás}

A kutatómunkának a marsi környezet vizes jellemzőivel kapcsolatos részét a COOP_NN_116927 program, a Föld térségében jellemző becsapódási ráta alapján a krátergyakoriság elemzéssel végzett marsi korbecslést az Excellence of Strategic R\&D centres, H2020 (GINOP-2.3.2-15-2016-00003) NKFIH projekt támogatta. 


\section{Hivatkozások}

de Vera J.-P., Dulai, S., Kereszturi, A., Koncz, L., Lorek, A., Mohlmann, D., Marschall, M., Pocs, T., 2014: Results on the survival of cryptobiotic cyanobacteria samples after exposure to Mars-like environmental conditions. International Journal of Astrobiology, 13(1): 35-44. https://doi.org/10.1017/S1473550413000323

Domagal-Goldman, S.D., Wright, K. E., Adamala, K., Arina de la Rubia, L., Bond, J., Dartnell, L.R., Goldman, A.D., Lynch, K., Naud, M. E., Paulino-Lima, I.G., Singer, K., Walter-Antonio, M., Abrevaya, X.C., Anderson, R., Arney, G., Atri, D., Azúa-Bustos, A., Bowman, J.S., Brazelton, W.J., Brennecka, G.A., Carns, R., Chopra, A., Colangelo-Lillis, J., Crockett, C.J., DeMarines, J., Frank, E.A., Frantz, C., de la Fuente, E., Galante, D., Glass, J., Gleeson, D., Glein, C. R., Goldblat, C., Horak, R., Horodyskyj, L., Kaçar, B., Kereszturi, A., Knowles, E., Mayeur, P., McGlynn, S., Miguel, Y., Montgomery, M., Neish, C., Noack, L., Rugheimer, S., Stüeken, E.E., Tamez-Hidalgo, P., Imari Walker, S., Wong, T., 2016: The Astrobiology Primer v2.0. Astrobiology, 16(8): 561-653. https://doi.org/10.1089/ast.2015.1460

Ettahri, M.A., Kereszuri, A., Hargitai, H., 2018: Topographical and morphological analysis of Mawrth Vallis to target ExoMars rover. 49th Lunar and Planetary Science Conference (LPSC), \#2448. https://www.hou.usra.edu/meetings/lpsc2018/pdf/2448.pdf

Hargitai, H.I., Gulick, V.C., Glines, N.H., 2017: Discontinuous drainage systems formed by highland precipitation and ground-water outflow in the Navua Valles and southwest Hadriacus Mons regions, Mars. Icarus, 294: 172-200. https://doi.org/10.1016/j.icarus.2017.03.005

Hargitai, H.I., Gulick, V.C., Glines, N.H., 2018: Paleolakes of Northeast Hellas: Precipitation, Groundwater-Fed, and Fluvial Lakes in the Navua-Hadriacus-Ausonia Region, Mars. Astrobiology, 18: 1435-1459. https://doi.org/10.1089/ast.2018.1816

Hargitai, H., Kereszturi, A. (eds.),: 2015: Encyclopaedia of Planetary Landforms. Springer. New York-Heidelberg-Dordrecht-London. 2460 p. ISBN 978-1-4614-3133-6.

Hauber, E., Orgel, Cs., van Gasselt, S., Reiss, D., Johnsson, A., Ramsdale, J., Balme, M., Conway, S., Costard, F., Gallagher, C., Kereszturi, A., Platz, T., Séjourné, A., Skinner, J., Swirad, Z., Łosiak, A., 2015: Mapping Mars' northern plains: origins, evolution and response to climate change - a new overview of recent ice-related landforms in Acidalia Planitia. EGU General Assembly 2015, held 12-17 April, 2015 in Vienna, Austria. id. 15566. Bibcode: 2015EGUGA.1715566H, http://meetingorganizer.copernicus.org/EPSC2015, id.EPSC2015-737

Horváth, A., Kereszturi, A., Bérczi, S., Sik, A., Pócs, T., Gánti, T., Szathmáry, E., 2009: Analysis of Dark Albedo Features on a Southern Polar Dune Field of Mars. Astrobiology, 9(1): 90-103. https://doi.org/10.1089/ast.2007.0212

Kapui, Zs., Kereszturi, A., Kiss, K., Szalai, Z., Újvári, G., Hickman-Lewis, K., Foucher, F., Westall, F., 2018: Fluvial or aeolian grains? Separation of transport agents on Mars using Earth analogue observations. Planetary and Space Science, 163: 56-76. https://doi.org/10.1016/j.pss.2018.06.007

Kereszturi, A., 2012a: Mars - fehér könyv a vörös bolygóról. Magyar Csillagászati Egyesület, Budapest. 189p. ISBN 9789638759757

Kereszturi, A., 2012b: Review of wet environment types on Mars with focus on duration and volumetric issues. Astrobiology, 12(6): 586-600. https://doi.org/10.1089/ast.2011.0686

Kereszturi, A., 2013a. Paleoflood reconstruction in the Gale crater of Mars. Astronomische Nachrichten, 334: 944-947. https://doi.org/10.1002/asna.201211966 
Kereszturi, A., 2013b. An unnamed fluvial valley system formed under different climates at Xanthe Terra, Mars. Planetary and Space Science, 85: 220-231. https://doi.org/10.1016/j.pss.2013.06.007

Kereszturi, A., Orgel, Cs., 2018: Proposed elements and an approach to evaluate the astrobiology potential of landing sites on Mars. (ed.: Mehler, N.) Research Advances in Astronomy, Nova Science Publisher Inc., New York. 89-118.

URI: http://real.mtak.hu/id/eprint/90460

Marschall, M., Dulai, S., Kereszturi, A., 2012: Migrating and UV screening subsurface zone on Mars as target for the analysis of photosynthetic life and astrobiology. Planetary and Space Science, 71: 146-153. https://doi.org/10.1016/j.pss.2012.05.019

Marschall, M., Hilyakiné, K.M., Gyollai, I., Józsa, S., Kereszturi, Á., 2015: Basalt weathering experiment in sulfuric acid brine to better understand Martian mineral alterations. 46th Lunar and Planetary Science Conference (LPSC), \#1333. https://www.hou.usra.edu/meetings/lpsc2015/LPSC2015 Program.pdf

Pál, B., Kereszturi, A., 2017: Possibility of microscopic liquid water formation at landing sites on Mars and their observational potential. Icarus, 282: 84-92. https://doi.org/10.1016/j.icarus.2016.09.006

Pál B., Kereszturi A. 2020. Annual and daily ideal periods for deliquescence at the landing site of InSight based on GCM model calculations. Icarus 340, 113639. https://doi.org/10.1016/j.icarus.2020.113639

Rauhala, A. I., Kostama, V.-P., 2012. Palos crater and Tinto Vallis, Mars: Analysis of proposed fluvial and volcanic scenarios. European Planetary Science Congress, id. EPSC2012-444. https://meetingorganizer.copernicus.org/EPSC2012/EPSC2012-444.pdf

\section{ORCID}

Steinmann V. (D) https://orcid.org/0000-0001-5233-6436 